Indonesian Journal of EFL and Linguistics

Vol. 4 No. 2, 2019

eISSN: 2503-4197, pISSN: 2527-5070

www. indonesian-efl-journal.org

\title{
Distinctive Features Analysis of Foreign Language Borrowing Words in Javanese Language Found in Panjebar Semangat Magazine
}

\author{
Linda Aprillianti \\ Diponegoro University \\ e-mail: lindaaprillia29@gmail.com
}

\begin{abstract}
:
The Javanese language belongs to language which has unique phonological system. There are so many foreign language has influenced the development of Javanese. This study is intended to examine the sound change of borrowing word of foreign language in Javanese which is found in Panjebar Semangat magazine. The data is taken from Panjebar and checked using old Javanese dictionary. This study belongs to descriptive qualitative research and used Simak method and Non Participant Observation in collecting the data. The data analysis is done by using Padan method. The result of the study reveals three sound changes of vowels sound and four phonological rules. Then, there are four types of sound change and four phonological rule of consonant sound. The result showed that the sound change of borrowing word in Javanese is influenced by the differences of phonological system between Javanese and the foreign language.
\end{abstract}

Keywords: borrowing words, distinctive features, foreign language, generative phonology, Javanese

\section{INTRODUCTION}

Cultural contact between Javanese and foreign people in the past influence the development of Javanese language. Jones (2008) mentioned, there are ten languages that become language donor in Indonesia. The donor languages are Dutch, Sanskrit, Arabic, Hindi, Tamil, Latin, Japanese, Chinese, Persian and Portuguese. Through the entry of other nations into Indonesia, the foreign language indirectly also entered and influenced the development of Javanese language. Sanskrit is the oldest language that first entered into Indonesia because Sanskrit vocabulary has exceeded Indonesian Journal of EFL and Linguistics, 4(2), 2019 


\section{Linda Aprillianti}

three periods in Javanese language development: (1) Old Javanese, (2) Middle Javanese, and (3) Modern Javanese. In its history, the Sanskrit language entered Indonesia during the period of ruling the Srivijaya kingdom. Sanskrit is a foreign language that contributes a lot to the Javanese vocabulary. This can be seen from there are many Sanskrit vocabularies which found in Javanese. After Sanskrit, Arabic entered Indonesia due to the time of Islamic establishment.

The Arabic language is used during the trading between Javanese people and Arabic people. After Arabic, Dutch entered Indonesia during the colonial period. The research related to distinctive feature analysis of borrowing words in Javanese had been conducted before. Some of researcher, such as Zen (2016), Perwira (2016) and As Samer (2015) has done a research about Sanskrit, Arabic and Dutch borrowing words in Javanese using generative phonology theory. The result of those studies revealed that the sound changing of Sanskrit, Arabic and Dutch borrowing words in Javanese is caused by the differences of phonological system between Sanskrit, Arabic, Dutch and Javanese. Then, Putradi (2016) which did the research which purposed to examine the phonological process of Sanskrit borrowing words and created the rules which showed the sound changing .Then, Nafisah (2017) discussed the sound change of some languages like Javanese, Arabic, and Zoque using generative phonology theory. The results of this study suggest that sound changes occur because they are influenced by affixation. Aside from research about borrowing words in Javanese, there is also other research which discussed phonological process using generative phonology in different language. There also some of researchers (Putu, Nyoman Seri, \& Suparwa, 2015; Obied, 2015; Indrawati 2015; Sutarsih, 2017; Salem Alqahtani, 2018; Al-Hindawi \& Al-Aadili, 2018) which have studied a phonological process of other language instead of Javanese using generative phonology theory. Although all of the studies have used the same theory as the writer used in this journal, but they did not created the rules of processes using distinctive features.

In other way, Javanese is also associated with several branches of linguistics such as Phonology. Phonology discusses the formation of sounds and sounds that are heard and concerned with the function of sound as a means of communication. Generative phonology was first introduced by Noam Chomsky, in generative phonology we learned about the process of changes sound so that we know about phonological rules.

Therefore, several analyzes were carried out that could prove this. Thus, the Javanese language can function properly. The use of various foreign languages in the community with these various objectives is clearly indirectly caused by the absence of appropriate and appropriate word equivalents to replace a particular word, both meaningfully and conceptually from the intended word. This is due to the impact of cultural contact with linguistic contacts. This study is headed to describe the sound change of borrowing words from foreign language into Javanese which 
found in Panjebar Semangat magazine through distinctive feature analysis. This study is important to be discussed because in Javanese there are many words that come from foreign languages which are need to examine in terms of phonology. This study was conducted to find out how the process of sound change in borrowing word could happen.

\section{LITERATURE REVIEW}

\subsection{Phonology Generative Transformational and Distinctive Features}

This study used generative phonology and Distinctive feature analysis theory which is developed by Schane (1973). The writer uses transformational generative phonology as a reference because this theory examines more deeply about the phonological aspects compared to the grammatical aspects of linguistic rules. Generative phonology also has the most outstanding advanced method to explain research related to phonological process.

Hall (2001) explained that distinctive features theory can solve phonological problem despite the complexity. This theory formulates rules that can explain phonological phenomena produced by native speaker of language. In distinctive features, there are three important features that should be known, such as major of class features, manner features, and place or articulation features. Major class features consist of syllabic, sonorant and consonantal. Sounds which belong to [+syllabic] are vowels sound, then for consonants sound, they belong to [-syllabic]. Instead of syllabic, there are also sonorant and consonantal sound. The sonorant refers to resonant quality of sound, vowels sound are included in [+sonorant], then for consonants sound, there are only nasal, liquid and semivowels which are included in [-sonorant]. The next features are manner features. Manner features consist of continuant, delayed released, strident, nasal and lateral. Then for place of articulation features, there are coronal and anterior. Anterior are produced by central of constriction as a source of sound in front of alveolar ridge. Then, the sound belongs to coronal if there is a gust of air passing through it, and the position of the tongue is neutral.

\subsection{Phonological Process}

Phonological processes try to find and explain the process of saying a word in relation to language skills. The phonological process is a systematic sound change that affects certain sound patterns and classes. Through the phonological process, this study will evaluate more related to borrowing words using distinctive features. Kenstowicz \& Kisseberth (1979) mentioned there are four types of phonological processes namely, assimilation, syllable structure, weakening and strengthening and the last is neutralization. The explanation of phonological process is described as follow:

\section{Assimilation}




\section{Linda Aprillianti}

Assimilation is a process of sound change where a sound is influenced by the other sound which has the same environment. Assimilation is phonetic sound change due to influences that are before or after. Assimilation is also referred to as the process of sound change which causes it to be similar or similar to other sounds nearby. The assimilation rule can be formulated as follow:

$$
\mathrm{B} \rightarrow \mathrm{C}
$$

\section{Syllable structure}

The syllable structure content deletion and insertion process, they are happen when there is a vowel or consonant sound which is deleted or inserted. A deletion rule is formulated like $\mathrm{V} \rightarrow \varnothing$, then for insertion process, it is formulated like $\emptyset \rightarrow \mathrm{V}$.

\section{Weakening and strengthening}

This process is a process when a simple syllable changing into the complex syllable. For example when sound [a] changing into sound [ə] it is belongs to weakening because sound [ə] belongs to weak sound. Then, if sound [ə] changing into sound [a], it belongs to strengthening.

\section{Neutralization}

This process occurs if there is a distinction of phonology which is reduced in particular environment.

\section{RESEARCH METHODOLOGY}

\subsection{Data}

The data used in this study is the list of borrowing words which is found in Panjebar Semangat Magazine 27th Edition of July 7, 2018. Those borrowing words came from Dutch, Sanskrit and Arabic. The focus of this study is consonant sound change of borrowing words, so the data of this study will be served at the form phonetic transcription.

\subsection{Method of Data Collection}

In this study, the writer used Simak method and Non Participant Observation. The writer used some sources to transcript the data from orthography into phonetic transcription. In transcribing the borrowing word from Dutch, and Arabic is checked using loanword in Indonesian (Jones, 2008). The last, data from Sanskrit is checked using book Sanskrit in Indonesian written by Gonda (1998).

\subsection{Method of Data Analysis}

This study is used more than one language as data, so the method used in this study is Padan method (Sudaryanto, 1993). This method is used to match the elements of the language that have been analyzed, namely the foreign language absorption words in the Javanese language found in the magazine Panjebar Semangat. Through the 
comparison, it can be seen the sound changes that occur in the absorbing process of the foreign language.

\section{FINDINGS}

\subsection{Vowels Sound Change}

Based on the data which is collected, the writer found there some vowels change of foreign language borrowing words into Javanese language. The sound changes which are found by the writer are long vowel sound change, short vowel sound change and vowel insertion.

\subsubsection{Long Vowel Sound}

Based on the data, the writer found the changing of [+long] vowel sound into [-long] vowel sound. The sample of data can be seen as follow:

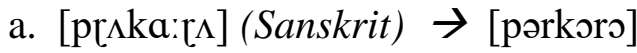
b. [bha:nd $\Lambda$ (Sanskrit) $\rightarrow$ [bondo]
c. $[\mathrm{s} \Lambda \mathrm{nda}: 1]($ Dutch $) \rightarrow[\mathrm{s} \Lambda \mathrm{nd} \Lambda \mathrm{l}]$
d. $[\mathrm{ka}: \mathrm{rtgis}]($ Dutch $) \rightarrow[\mathrm{k} \Lambda \mathrm{rcis}]$
e. [m $\Lambda$ qa:m] (Arabic) $\rightarrow[\mathrm{m} \Lambda \mathrm{kom}]$

The samples of data above, there are two sounds changing from vowel sound $[a]$ into vowel sound [o] and vowel sound [a] changing into vowel sound $[\Lambda]$. By looking at the sound changing above, the phonological rules can be formulated as follow:

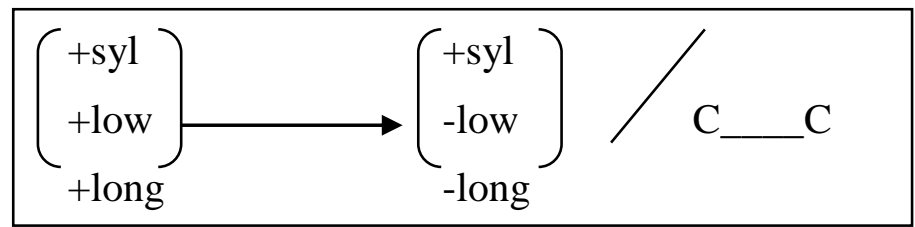

The rules above described that the foreign language from Sanskrit, Dutch and Arabic which have feature [+syl,+low,+long] changing into Javanese vowel sound with features [+syl,-low,-long] when the sounds are placed between two consonants sound. The sound changing happen because in phonological system of Sanskrit, Dutch and Arabic are consist of long vowel sound, this case is contrast with the phonological system of Javanese which does not have long vowel sound. Because of the differences, when the processes of absorption of the foreign language happen, vowel sound with long features changing into short vowel sound in Javanese.

\subsubsection{Short Vowel Sounds}

Instead of long vowel sound changing, the writer also found sound changing of vowel sound $[\Lambda]$ changing into vowel sound [ə] and vowel sound $[\Lambda]$ into vowel sound [o]. The sample of data is listed below:

a) $[$ prıka:rı] (Sanskrit) $\rightarrow$ [pərkərə] 


\section{Linda Aprillianti}

b) [bha:nd $\mathbf{\Lambda}$ (Sanskrit) $\rightarrow$ [bond

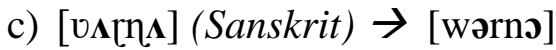

d) $[$ cs ritu] (Sanskrit) $\rightarrow$ [corita]

e) $[\mathrm{q} \Lambda \mathrm{mis}]($ Arabic) $\rightarrow[\mathrm{kəmis}]$

If we observe sound changes in the data above, there is sound changing of sound $[\Lambda]$ $\rightarrow[\ni]$ and sound $[\Lambda] \rightarrow[0]$. Based on the sound changing above, the writer created two phonological rules as follow:

Phonological rule 1:

Vowel sound [1] changing into vowel sound [ə]

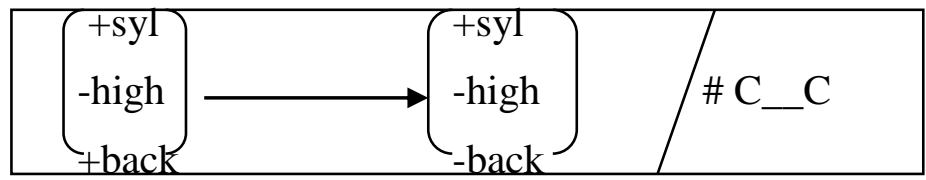

The first rule showed the sound changing of vowel sound $[\Lambda]$ into vowel sound [ə]. The rule above described the vowel sound $[\Lambda]$ which has features $[+$ syll,high,+back] changing into vowel sound [ə] with features [+syll,-high,-back]. This changing could happen if the position sound $[\Lambda]$ is placed in the middle of consonants sound.

Phonological rule 2:

Vowel sound [ 1$]$ changing into vowel sound [o]

As the writer mentioned before, vowel sound $[\Lambda]$ not only change into vowel sound [ə]. In current position, vowel sound $[\Lambda]$ also changing into vowel sound [o]. So, in this case there is a change from unrounded vowel sound into rounded vowel sound. The phonological rule is created as follow:

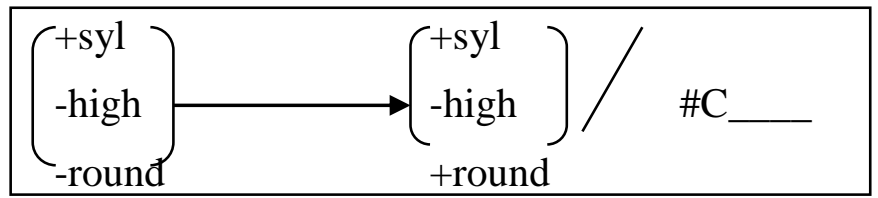

The rule above described vowel sound which has feature [+syl,-high,-round] changing into vowel sound [+syl,-high,+round] after consonants sound. If it is seen from the changes, it can be concluded that the sound $[\Lambda]$ can change to [ə] and [0] depending on the environment or its position in a word.

\subsubsection{Vowel Insertion}

Another phonological process found in this study is Insertion. Insertion belongs to syllable structure process. This process happens because there is another sound 
which is inserted in to syllable. The insertion process of borrowing word which is found in Panjebar Semangat magazine is listed as follow:
a. $[\mathrm{krt} \Lambda]($ Sanskrit $) \rightarrow[$ kərto]
b. $[\mathrm{w} \Lambda \mathrm{ls}]($ Dutch $) \rightarrow[\mathrm{b} \Lambda \mathrm{los}]$
c. [stro:p] $($ Dutch $) \rightarrow$ [sətrop]
d. [stro:m] (Dutch) $\rightarrow$ [sətrum]

The sample of data above showed there is insertion of vowel sound [ə] between two consonant which forming into cluster. For example, on the sample (a) there is insertion of vowel [ə] on the word [krt $\Lambda$ ]. The vowel sound [ə] is inserted into consonant cluster [kr]. The insertion is changing the word [krt $\Lambda$ ] into [kərto]. By looking at the data above, the writer created phonological rule as follow:

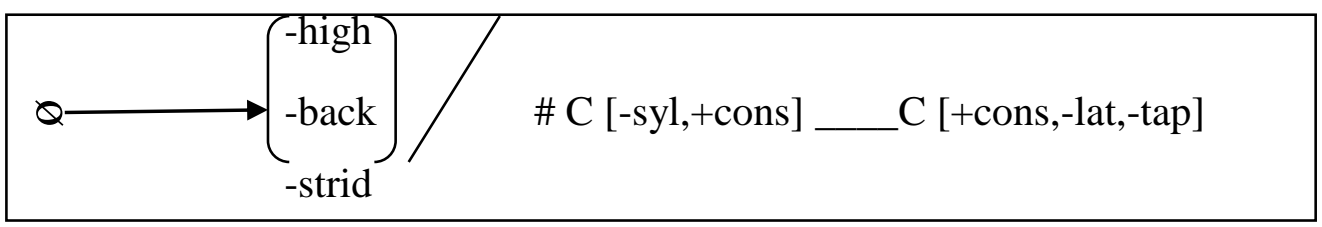

The rule above explains the insertion of vowel sound [ə] on the consonant cluster of words. The insertion of vowel sound [ə] is aimed to facilitate speakers of Javanese in their pronunciation. The rule also showed that the insertion of vowel sound [ə] not only appear on consonant cluster which take position as an onset but also it appears on consonant cluster which has position as coda.

\subsection{Consonants Sound Change}

Sound change is not only happen to vowel sound but also consonants sound. The writer found some consonants sound changing of Sanskrit, Dutch and Arabic borrowing word in Panjebar Semangat magazine. The sound changes are nasal sound change, voiceless uvular plosive sound change, voiced labio-dental approximant sound change, and voiced retroflex flap sound change. The explanation related to consonants sound changes are examined as follow:

\subsubsection{Nasal Sound Change}

The first consonant sound which is found in the data is nasal sound change. The list of sample data can be seen below:

a. [bha:nd $\Lambda$ ] (Sanskrit) $\rightarrow$ [bondo]

b. $[\mathrm{d} \Lambda \mathrm{n} \mathrm{d} \Lambda]($ Sanskrit $) \rightarrow[\mathrm{d} ə \mathbf{n d} \mathrm{b}]$

c. $[\mathrm{ka:}[\Lambda \mathbf{\eta} \Lambda]$ (Sanskrit) $\rightarrow$ [kərono] 


\section{Linda Aprillianti}

Based on the sample above, the nasal sound [n] changes into nasal sound [n]. This case happens when the nasal sound is placed after vowel sound $[\Lambda]$. If we observed based on the sound changing above, the phonological rules can be formulated as follow:

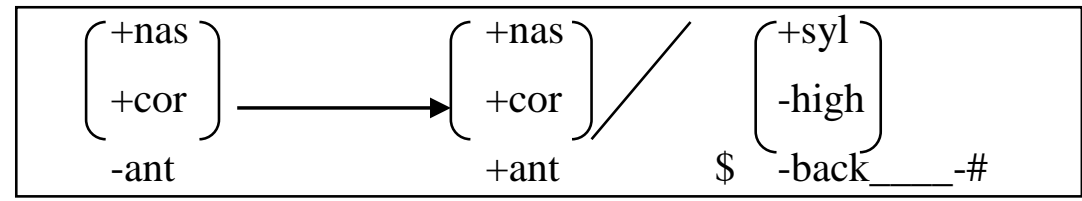

The rule above described that nasal sound [n] which has feature [+nas, + cor,-ant] changing into nasal sound [n] with feature [+nas,+cor,+ant] if it is placed after vowel sound with feature [+syl,-high,-back]. This changing is aimed to make Javanese native speaker pronounce the words easier.

\subsubsection{Voiceless Uvular Plosive Sound Change}

Another consonants sound which is found in the data is the sound changing of voiceless uvular plosive into voiceless velar plosive consonant. The sound changing can be observed on the data below:
a. $[\Lambda \mathbf{q l}]$ (Arabic) $\rightarrow[\Lambda \mathbf{k} \Lambda \mathbf{l}]$
b. $\left[\Lambda \mathrm{k}^{\mathrm{h}} 1 \Lambda \mathbf{q}\right]$ (Arabic) $\rightarrow[\Lambda \mathrm{k} 1 \Lambda \mathbf{k}]$
c. $[\mathrm{m} \Lambda \mathbf{q a}: \mathrm{m}]($ Arabic $) \rightarrow[\mathrm{m} \Lambda \mathbf{k}$ m $]$
d. $[\mathbf{q} \Lambda$ bul $] \quad$ (Arabic) $\rightarrow[\mathbf{k} \Lambda$ bul $]$

The sound changing of consonants sound $[\mathrm{q}]$ into consonant sound $[\mathrm{k}]$ is mostly come from Arabic borrowing word. The sound changing occur when the consonants sound [q] is placed before vowel sound $[\Lambda]$ at the first syllable or it is placed after vowel sound $[\Lambda]$ at the first word. If we take a look on the distinctive feature both consonant $[\mathrm{q}]$ and $[\mathrm{k}]$ almost have the similar feature, the differences are only that consonant sound [k] has [+high] feature then the consonant sound [q] has [+high] feature. Based on the sample of data above, the writer created phonological rule as follow:

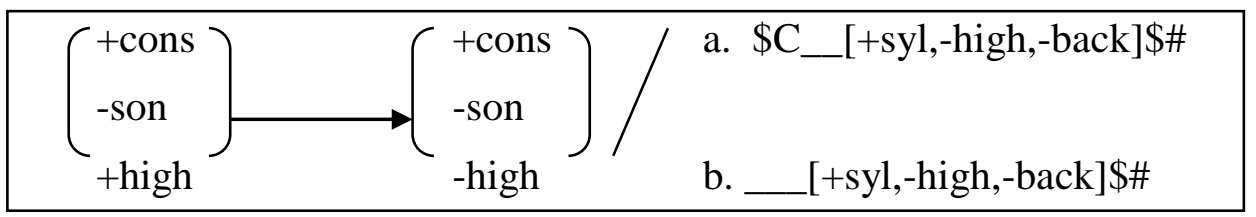

The phonological rule above explain that consonant sound [q] with feature [+cons,son,+high] changing into consonant sound [k] with feature [+cons,-son,-high] if placed before vowel sound $[\Lambda]$ at the first syllable or it is placed before vowel sound $[\Lambda]$ when its position at the first word. The changing is caused the differences of 
distribution consonants between Arabic and Javanese. In Javanese, the consonants sound [q] is rarely used or almost never used so that it is replaced by consonant sound [k] which has similar feature with the consonant [q] to help the Javanese people pronounce the word easier.

\subsubsection{Voiced Labio-Dental Approximant Sound Change}

Some of data which is collected also found some of sound changing of consonant sound [v] into semivowel [w]. The sample of data has listed as follow:

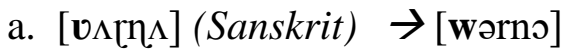
b. $[\mathrm{v} \wedge \mathrm{j} \Lambda \mathrm{s}]($ Sanskrit $) \rightarrow[\mathrm{w} \wedge \mathrm{j} \Lambda \mathrm{h}]$

Based on the sound changing above, it can be concluded that consonant sound $[v]$ changing into semivowel [w] if that sound is followed by vowel sound $[\Lambda]$ and placed at the first syllable. The phonological rule is represented as follow:

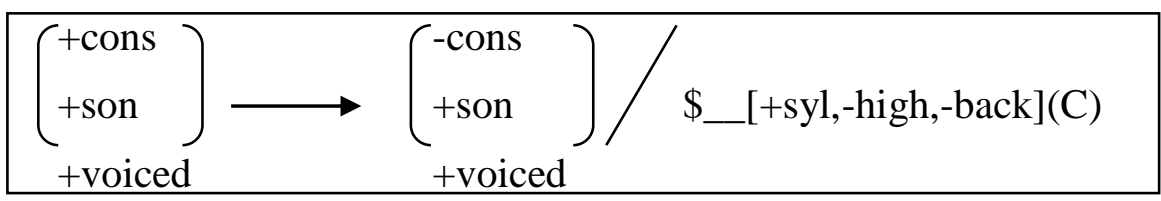

The rule above explained that consonant sound [v] with feature [+cons,+son,+voiced] changing into semivowel sound [w] with feature [cons, + son, + voiced] before vowel sound $[\Lambda]$ which has feature [+syl,-high,-back] at the first syllable. The sound changing is influenced by the differences of phonological system between Sanskrit and Javanese which is in Javanese do not recognize the consonant sound [v].

\subsubsection{Voiced Retroflex Flap Sound Change}

The last consonant sound which is found by the writer is consonant sound [r]changing into consonant [r]. The sound changing can be observed by looking the sample of data below:

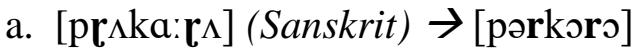
b. $[\operatorname{ka:} \wedge \Lambda \Lambda]($ Sanskrit $) \rightarrow[$ kərono]
c. $[\operatorname{n} \Lambda \mathrm{g} \Lambda \mathbf{r} \Lambda]($ Sanskrit $) \rightarrow[$ nogoro]
d. $[\mathrm{k} \Lambda \mathrm{rk} \Lambda 6 \Lambda]$ (Sanskrit) $\rightarrow[$ rəkəso]

The sound changing above, there sound change of consonant sound $[r] \rightarrow[r]$. So, the phonological rule is formulated as follow:

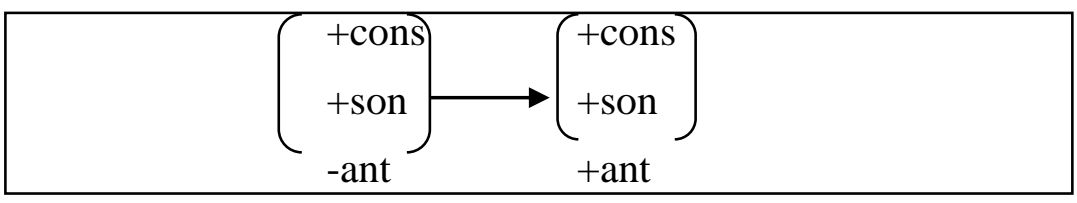

Indonesian Journal of EFL and Linguistics, 4(2), 2019 


\section{Linda Aprillianti}

From the phonological rule above, it described the sound change of consonant $[\mathrm{r}]$ which has feature [+cons,+son,-ant] into consonant sound trill [r] with feature $[+$ cons, + son, + ant $]$. Because of Javanese language do not have consonant sound $[\mathrm{r}]$ in their phonological system, so the consonant sound flap $[\mathrm{r}]$ in Sanskrit is replaced by consonant trill [r].

\section{DISCUSSION}

Based on the result above, this study revealed that in the process of borrowing word from Arabic into Javanese, Dutch into Javanese and Sanskrit into Javanese can caused sound change. The result of this study is supported by Perwira (2016) and Zen (2016) which stated the cause of sound change in borrowing process between Javanese and another language is the differences of phonological system. Another statement related to phonological process using generative phonology is derived from Nafisah (2017). Through her studies, she claimed that most of phonological process of any language is caused by affixation, the cause also showed by giving the phonological rules of how the sound can change into another sound. However, after doing the analysis of distinctive feature between foreign language and Javanese, this study agree on the statement of Zen (2016) and Perwira (2016) which stated that phonological system of language give big impact on borrowing process of foreign language into Javanese. In this case, the writer found that almost all types of sound changing process are influenced by internal and external factors. By looking at the external factor, the sound changing is caused by the differences of phonological system and the differences of sounds distribution between Arabic, Dutch, Sanskrit and Javanese. Then, for the internal factor, those changing because of adjacent sounds influence each other. This effect causes some of sounds which almost have similar features changed. In order to prove how the borrowing process of foreign language into Javanese can cause sound changing, the writer used Generative Transformational phonology theory and Distinctive feature theory.

Through Generative Transformational phonology theory and Distinctive feature theory, this theory can show how a sound is changing into another sound. Phonological rules showed in this theory is described how a phoneme realizing the environment of their allophones. The used of this theory to solve phonological problem also supported by some of researcher (As Samer, 2015; Salem Alqahtani, 2018; Putu et al., 2015). By using this theory, the result showed some of sound changing from foreign language into Javanese as follow:

1. The changing of vowel sound which has features [+long] into [-long]. This changing can be caused by the phonological system of Javanese which not have sound with [+long] feature.

2. Sound changing of vowel sound $[\Lambda]$ into vowel sound [o]. In this case, the distinctive features analysis showed that borrowing process of foreign language in Javanese can cause a changing from unrounded vowel sound into rounded vowel sound. 
3. This theory also showed that vowel sound $[\Lambda]$ can also change into vowel sound [ə]. In this case, the changing is called weakening or lenition, because vowel sound [ə] belongs to weak sound and has no positive features.

Aside from vowel sound changing, the distinctive feature analysis also showed the changing of consonants sound. Consonants sound changing of foreign language into Javanese are nasal sound [n], labio-dental approximant [v], uvular stop [q] and retroflex sound [d]. Almost of consonants sounds which rarely used in Javanese phonological system is replaced by another consonant sound which has similar feature with consonants sound from foreign language.

Based on the finding above, this study revealed that through distinctive features analysis, borrowing words of foreign language in Javanese is undergone assimilation and syllable structure process. Then, the phonological rules which used in this study are features changing rule and insertion rule.

\section{CONCLUSION}

The result of the study provides some sound change of both consonant and vowels sound. In vowels sound change, the writer found two types of phonological process namely features changing process and insertion process. There are four phonological rules created to prove the sound changing. Then, in consonant sound the writer only found assimilation with four different sounds changing and created four phonological rules. Based on the result, the dominant factors which influence the sound change are the differences of phonological system between Javanese, Sanskrit, Arabic and Dutch. Most sounds from Sanskrit, Dutch and Arabic that are not found in the vowel and consonant distributions of the Javanese language will be adjusted. Based on this study, it can be concluded that the differences of phonological system of each language also influence their phonological process. Although, language can come from the same language family, but if they have different distribution on vowel and consonant, that language will produce different phonological system.

\section{REFERENCES}

Al-Hindawi, D. F. H., \& Al-Aadili, N. M. (2018). The Basic Tenets of Generative Phonology. Journal of Education and Practice, 10.

As Samer, M. A. A. S. (2015). Phonetic and Phonological Adaptations of English Loanwords into Iraqi Arabic: A Generative Study. Journal of the College of Arts. University of Basra, 73, 46.

Gonda, J. (1998). Sanskrit in Indonesia (Repr). New Delhi: Internat. Acad. of Indian Culture.

Hall, T. A. (Ed.). (2001). Distinctive feature theory. Berlin; New York: Mouton de Gruyter. 


\section{Linda Aprillianti}

Indrawati, D. (2015). Proses Fonologis Dalam Pengadopsian Kata Bahasa Indonesia Ke Dalam Bahasa Cia-Cia di Kabupaten Buton, Sulawesi Tenggara. Jurnal Pena Indonesia, 1(1), 96. https://doi.org/10.26740/jpi.v1n1.p96-104

Jones, R., Indonesian Etymological Project, KITLV Office Jakarta, \& Yayasan Obor Indonesia (Eds.). (2008). Loan-words in Indonesian and Malay. Jakarta: KITLV-Jakarta : Yayasan Obor Indonesia.

Kenstowicz, M. J., \& Kisseberth, C. W. (1979). Generative phonology: Description and theory. New York: Academic Press.

Nafisah, S. (2017). Proses Fonologis dan Pengkaidahannya dalam Kajian Fonologi Generatif. DEIKSIS, 9(01), 70. https://doi.org/10.30998/deiksis.v9i01.940

Obied, I. M. (2015). Phonological Rules. https://doi.org/10.13140/rg.2.1.2516.7448

Perwira, Y. K. (2016). Proses Penyerapan Bahasa Belanda ke dalam Bahasa Jawa ( Sebuah Kajian Fonologi Generatif Transformational) (Thesis). Diponegoro University, Semarang.

Putradi, A. W. A. (2016). Pola-Pola Perubahan Fonem Vokal dan Konsonan dalam Penyerapan Kata-Kata Asing Ke Dalam Bahasa Indonesia: Kajian Fonologi. Arbitrer Journal, 3(2), 96-112.

Putu, A. A., Nyoman Seri, N. L., \& Suparwa, I. N. (2015). Adaptasi Kosakata Bahasa Bali Dalam Bahasa Melayu Loloan Bali. LITERA, 14(1). https://doi.org/10.21831/ltr.v14i1.4404

Salem Alqahtani, M. (2018). Phonological Adaptation of Arabic Loanwords in Sabzevari Persian: Metathesis and Vowel Epenthesis. Linguistics and Literature Studies, 6(4), 188-195. https://doi.org/10.13189/lls.2018.060405

Schane, S. A. (1973). Generative phonology. Englewood Cliffs, N.J: Prentice-Hall.

Sudaryanto. (1993). Metode dan aneka teknik analisis bahasa: Pengantar penelitian wahana kebudayaan secara linguistis. Yogyakarta: Duta Wacana University Press.

Sutarsih, S. (2017). Penanda Fonologi Bahasa Jawa Dalam Tuturan Masyarakat Tionghoa di Gang Baru Semarang. Aksara, 29(1), 89. https://doi.org/10.29255/aksara.v29i1.103.89-102

Zen, A. L. (2016). Perubahan Fonologis Kosakata Serapan Sansekerta Dalam Bahasa Jawa (Analisis Fitur Distingtif Dalam Fonologi Transformasi Generative) (Thesis, Diponegoro University). Retrieved from http://eprints.undip.ac.id/48453/ 